\title{
ISLAM DAN INDONESIA ABAD XIII-XX M DALAM PERSPEKTIF SEJARAH HUKUM
}

\author{
Fabian Fadhly \\ Mahasiswa Magister Sejarah Sejarah Kebudayaan Islam, \\ UIN Sunan Gunung Djati \\ email: fabianfadhly@ymail.com \\ disampaikan 5/9/17 - di-review 15/11/17 - diterima 25/12/17 \\ DOI: $10.25123 /$ vej.2683
}

\begin{abstract}
Historical reality shows that Islam has, since centuries, been an inseparable part of societies living in the Indonesian archipelago. Islamic law (fiqh) has been growing and developing during the high days of Islamic sultanates, Dutch-colonial times and independent Indonesia. The author, using a historical perspective, traces how Islamic law transforms during and with those changes. One important finding is that Indonesian independence has been an important turning point in Islamic law development. The state promulgated numerous laws and regulation allowing Moslems to use and implement Islamic law in various parts of their daily lives relating to marriage, inheritance, religious courts and lastly Islamic banking.
\end{abstract}

Keywords: Islam; Indonesia; Legal History.

\begin{abstract}
Abstrak
Realita sejarah menunjukkan bahwa sudah sejak dahulu, Islam menjadi bagian dari kehidupan masyarakat di Nusantara. Hukum Islam (fiqih) yang diberlakukan, sejalan dengan kebutuhan masyarakat, terus mengalami perubahan dan transformasi sejak dari era kerajaan-kerajaan Islam di Nusantara, zaman penjajahan dan kemudian era Indonesia merdeka. Dengan menggunakan metoda historis dengan pendekatan yuridis, penulis akan menelusuri proses transformasi tersebut. Satu hal penting yang muncul dari penelusuran sejarah ini adalah bahwa kemerdekaan Indonesia merupakan titik balik bagi perkembangan Islam. Sejak zaman kemerdekaan, muncul pelbagai aturan negara yang memberikan keleluasaan bagi umat Islam untuk mengamalkan ajaran Islam, khususnya hukum Islam di bidang perkawinan, waris, peradilan agama, perbankan syariah (ekonomi Islam).
\end{abstract}

Kata kunci:

Islam; Indonesia; Sejarah Hukum.

\section{Pendahuluan}

Hamka mengemukakan bahwa sejarah panjang Islam berada di Indonesia dimulai pada abad 7 M dengan berhijrahnya bangsa Arab melalui Samudera Hindia dan melalui jalan darat. Perkampungan-perkampungan yang didirikan oleh bangsa Arab menjadi bukti Islam telah masuk pada abad tersebut. Tempat singgah 
yang berada di rute perdagangan daerah Malabar dan pulau Sailan merupakan bukti Indonesia menjadi bagian dari perluasaan kekuasaan Bani Umayyah pada saat itu, melalui pendekatan ekonomi atau transaksi perniagaan. ${ }^{1}$

Sejarah panjang Islam memasuki dan berada di wilayah Indonesia tidak lepas dari pengaruh kekuasaan Islam yang mengalami perluasan wilayah penyebarannya. Khulafa ar-Rasyidin merupakan pelopor ketercapaian hal tersebut, yang dilanjutkan oleh Dinasti Umayyah dan Dinasti Abbasiyah. Ketiga pemerintahan di wilayah Semenanjung Arab merupakan representasi dari kelanjutan penyebaran agama Islam ke berbagai wilayah di Asia, Eropa dan Afrika yang dimulai dari abad $7 \mathrm{M}-13 \mathrm{M}$ atau dalam terminologi Harun Nasution dikenal dengan Periode Islam Klasik. ${ }^{2}$

Masuknya Islam menandai munculnya era baru dalam berbagai aspek kehidupan yang berkembang di masyarakat Indonesia. Aturan-aturan hidup yang mulai menjadi bagian yang tidak terpisahkan mulai dipraktekkan atau diimplemantasikan dalam setiap aspek kehidupan. Aturan-aturan hidup tersebut tidak hanya berkaitan dengan aspek legalitas formal yang bernuansa hukum, melainkan pula nilai-nilai yang terkandung dalam ajaran agama Islam yang berkaitan dengan aspek kehidupan ekonomi, budaya, sosial kemasyarakatan bahkan politik yang menjadi bagian dari bagaimana Islam mendekatkan diri pada masyarakat Nusantara. ${ }^{3}$

Masa setelah periode kesultanan menjadi bagian lain yang terintergrasi dari perjalanan Islam melalui satu sisi kehidupan yang dibangun dari pemaknaan, perenungan, pemahaman, pelaksanaan baik menuju arah perkembangan maupun kemunduran. Perkembangan dan kemunduran ini erat kaitannya dengan

1 Hamka, Sejarah Umat Islam IV, Bulan Bintang, Jakarta, 1976, hlm. I38. Hasil seminar menyimpulkan bahwa agama Islam telah berangsur-angsur datang ke Indonesia sejak abad-abad pertama Hijriyah atau sekitar abad ke-7 dan 8 Masehi , langsung dari Arab. Di antara para mubaligh Islam pertama ini terdapat orang-orang dari Malabar, Gujarat, dan Persia. Sekalipun mubaligh itu dari Malabar, Gujarat, dan Persia, para mubaligh tersebut hanya singgah sementara dan mereka berasal dari Arab (K.H.O. Gadjahnata, Sri-Edi Swasono, Masuk dan berkembangnya Islam di Sumatera Selatan, UI-Press, Jakarta, 1986, hlm. 12).

2 Lihat: Nyimas Umi Kalsum, Perkembangan Pemikiran Dan Peradaban Islam Pada Abad Modern, Jurnal Tamddun Vol 14, No. 2 (2014), hlm. 38.

3 Lihat: Alma'arif, Islam Nusantara: Studi Epistemologis Dan Kritis, ANALISIS: Jurnal Studi Keislaman, Volume 15, Nomor 2, Desember 2015. 
bagaimana Islam dan hukum yang terdapat di dalamnya dalam makna syar'i. Syar'i menunjukkan Islam dibangun melalui kesesuaian antara teks-teks dalam naskah suci yang dinamai al-Quran dengan perjalanan pewahyuan selama kurang lebih 23 tahun, bermulai dari tahun $583 \mathrm{M}$ dan berakhir pada tahun $623 \mathrm{M}$.

Perkembangan Islam serta ajaran-ajarannya terkait pengaturan kehidupan muslim di Indonesia, memiliki penguatan dalam membentuk apa yang dikenal saat ini dengan hukum Islam yang dipersamakan dengan fiqih pada era kekhalifahan Islam di wilayah bagian timur Dunia. Perkembangan yang cukup pesat di Indonesia menandai mulai bercampurnya Islam dengan kearifan lokal Indonesia yang secara langsung memunculkan keunikan-keunikan hukum Islam dalam tatanan/tata hukum Indonesia.

M. Idris Ramulyo mengungkapkan keterikatan yang erat mengenai mekanisme penentuan dan pengukuhan mengenai mekanisme aturan hukum yang berkembang di Indonesia, yang kemudian menjadi bagian dari ahwa alsyakhshiyyah, mu'malah, akhlaq, dan jinayah. M. Idris Ramulyo menarik mekanisme ini bermula dari zaman pra Kolonial Belanda dengan membaginya kepada tiga periode: pertama, periode tahkim atau mengangkat seseorang yang dipercaya menjadi wakil dari suatu peristiwa hukum dalam kategori ahwa alsyakhshiyyah. Kedua, periode ahl al-hal wa al-'aqdi atau mengangkat seseorang yang terpercaya dengan disertai kemampuan penguasaan ilmu fiqih menjadi qadhi. ${ }^{4}$ Ketiga, periode thauliyyah atau dalam dunia modern dilekatkan dengan teori delegation of authority. ${ }^{5}$

Pendapat M. Idris Ramulyo melalui periodesasi pengukuhan dan penetapan hukum Islam sebagai sebuah aturan kehidupan manusia di wilayah Indonesia, muncul melalui institusi lembaga yang dikenal dengan kerajaan mampu melaksanakan hukum Islam dalam wilayah kekuasaannya masing-masing. Kerajaan Samudera Pasai pada abad ke 13 M merupakan perintis dan pelopor

\footnotetext{
4 peran dari raja-raja Kesultanan Islam yang tidak hanya menempatkan diri sebagai sosok pemimpin, melainkan pula sosok ulama sebagai penyambung lidah Nabi saw. (Sosok ulama dan pemimpin ini dalam terminologi al-Mawardi dikatakan sebagai Ulama dan Umara. Lihat: alMawardi, al-Ahkam al-Sulthaniyyah)

5 M. Idris Ramulyo, Asas-Asas Hukum Islam )Sejarah Timbul dan Berkembangnya Kedudukan Hukum Islam dalam Sistem Hukum di Indonesia, Sinar Grafika, Jakarta, 1997, hlm. 53-54.,
} 
kerajaan Islam di Indonesia pada saat itu, ${ }^{6}$ kemudian diikuti oleh Kerajaan Demak, Jepara, Tuban, Gresik, dan beberapa kerajaan lainnya. ${ }^{7}$

Masa kerajaan-kerajaan Islam merupakan periode peran raja dalam menerapkan hukum Islam melalui pelaksanaan yang telah berlangsung lebih dari 2 abad yang diawali oleh Raja Kerajaan Samudera Pasai Sultan Malik As-Shaleh sebagai sosok ahli dalam bidang fikih menurut madzhab Syafi'i, dengan bantuan para ulama dari berbagai mancanegara serta dari qadhi (hakim) di mana sultan pertama dari kerajaan ini menerapkan berbagai keputusan-keputusan yang berkaitan dengan pelaksanaan hukum Islam di daerahnya. ${ }^{8}$

Kemunduran yang dialami oleh kesultanan Islam pada abad $16 \mathrm{M}$, membawa pengaruh yang cukup luas pada perubahan Hukum Islam, walaupun tetap menjadi bagian yang hidup dalam masyarakat Indonesia. Pengaruh kemunduran Kerajaan-Kerajaan Islam di Indonesia berbanding lurus dengan munculnya V.O.C (Vereenigde Oostindische Compagnie) sebagai perwakilan kolonialisme dengan motif perniagaan (perdagangan) yang menunjukkan mekanisme legalitas formalistis tersebut dengan memberikan penugasan kepada D.W. Freijer untuk menyusun Compendium. ${ }^{9}$

Pergantian penguasaan wilayah Indonesia dari Kerajaan-Kerajaan Islam ke V.O.C dan Kerajaan Belanda, tidak secara langsung mengubah keadaan masyarakat Indonesia dalam mengamalkan aturan-aturan Islam yang telah menyatu dalam

${ }^{6}$ Bukti Islam berkembang pada kerajaan Samuderai Pasai dicatat dalam catatan Ibnu Batutah ketika mengadakan perjalanan ke Kerajaan Samudera Pasai pada tahun 1345 , dalam tulisannya ia menyatakan kekagumannya terhadap perkembangan Islam dibawah pimpinan Sultan Malik Al-Zahir. (Feirul Maliq Intajalle, et all, Islamic Inheritance Law Among Muslim Minority Countries in Southeast Asia,Middle-East Journal of Scientific Research 12 (1), (2012), hlm. 12.

7 Amien Husein Nasution, Hukum Kewarisan (Suatu Analisis Komparatif Pemikiran Mujtahid dan Kompilasi Hukum Islam), Rajawali Pers, Jakarta, 2012, hlm. 2.

8 Anonim. Salah satu bukti penerapan dan pelaksanaan hukum Islam di Samudera Pasai dapat ditemukan dalam Prasasti Trengganu. Lihat: Rahimin Affandi Abd Rahim, Paizah Hj Ismail, Mohd Kamil Abd Majid, Nor Hayati Md. Dahlal, Batu Bersurat Terengganu: Satu Tafsiran Terhadap Pelaksanaan Syariah Islam, Jurnal Fiqh, No. 7 (2010).

${ }_{9}$ Mardani, Hukum Kewarisan Islam di Indonesia, Rajawali Pers, Jakarta, 2014, hlm. 140. Mardaini melanjutkan Compendium memuat hukum perkawinan dan kewarisan Islam dengan diperbaiki dan disempurnakan oleh ahli hukum Islam pada saat itu. Kitab hukum itu secara resmi diterima oleh Pemerintahan V.O.C tahun 1706 dan dipergunakan oleh pengadilan dalam menyelesaikan sengketa yang terjadi di kalangan umat Islam di daerah kekuasaan V.O.C. Kitab tersebut dikenal dengan dengan Compendium Freijer. 
ritualitas kehidupan beragama muslim Indonesia. Keadaan ini ditunjukkan dengan sikap penguasa Kolonial tetap mempertahankan lembaga peradilan agama (priesterraad) di wilayah Aceh, Jambi, Kalimantan Selatan dan Timur, Sulawesi Selatan, Sulawesi Utara, Gajo, Alas, Tapanuli dan Sumatera Selatan, dan Jawa, walaupun tetap berada di bawah landraden (pengadilan negeri). ${ }^{10}$

Pengakuan dari penguasa Kolonial Belanda terhadap hukum Islam yang ditunjukkan dengan tetap mempertahankan lembaga peradilan agama yang dilatar belakangi oleh pemberontakan-pemberontakan yang dilakukan oleh kaum muslim mulai dari abad 18-abad 19 dan berakhir dengan ditandai oleh Perang Padri di Aceh Tahun 1903, terdapat dalam Pasal 11 Algemene Bepaling van Wetgeving (A.B) dan Pasal 131 ayat (2) Indische Staatsregetling (I.S). ${ }^{11}$

Patut dipahami pengakuan yang muncul dari Pemerintah Kolonial Belanda tidak secara khusus mengembalikan hukum Islam sebagai sebuah tatanam hukum, yang muncul dan diterapkan sebagaimana terjadi pada masa Kerajaan-Kerajaan Islam berkuasa. Kamsi mengungkapkan, bagian terpenting yang tetap dipertahankan oleh Pemerintah Kolonial Belanda adalah memberikan kebebasan bagi masyarakat muslim Indonesia, untuk tetap menyelesaikan permasalahan atau sengketa yang muncul hanya dalam ruang lingkup perkawinan dan kewarisan. ${ }^{12}$

Fenomena atau keadaan yang menempatkan Islam dan aturan-aturan hukumnya di Indonesia, hanya berkaitan dengan pernikahan dan kewarisan, yang diselesaikan melalui lembaga peradilan agama terus berjalan (berlaku) sampai zaman kemerdekaan. ${ }^{13}$ Realita lain yang muncul mengenai hukum Islam tetap berada pada ruang lingkup ahwal al-syakhshiyyah (hukum keluarga) dikuatkan dengan Undang-Undang Nomor 7 Tahun 1989 tentang Peradilan Agama, yang

${ }^{10}$ Daniel S. Lev, Islamic Courts in Indonesia (A Study in the Political Bases of Legal Institutions), University of California Press, Los Angeles, 1972, hlm. 10-11.

${ }^{11}$ Saidus Syahar, Asas-Asas Hukum Islam, Alumni, Bandung, 1974, hlm. 113.

${ }^{12}$ Kamsi, Politik Hukum Dan Positivisasi Syariat Islam Di Indonesia, SUKA-Press UIN Sunan Kalijaga, Yogyakarta, 2012, hlm. 48.

${ }^{13}$ Lihat: Saidus Syahar, Asas-Asas Hukum Islam, Alumni, Bandung, 1978, hlm. 124-127. Saidus Syahar dalam bukunya ini merinci secara jelas mengenai bagian-bagian aturan Hukum Islam yang tetap diadopsi atau dipertahankan setelah masa kemerdekaan. Bagian-bagian tersebut tetap berada pada wilayah hubungan hukum yang muncul dari perkawinan dan kewarisan. 
hanya memiliki wewenang dan kekuasaan untuk memeriksa, memutus, dan menyelesaikan perkara-perkara perdata Islam. ${ }^{14}$

Tulisan ini dikedepankan sebagai usaha untuk memberikan pemahaman dan pemaknaan yang tepat, mengenai Islam dalam perjalanan sejarah bangsa Indonesia sebagai sebuah ajaran agama yang telah jauh memberikan pengaruh terhadap berbagai aspek kehidupan masyarakat Indonesia, terutama terkait dengan hukum Islam yang baik disadari maupun tidak disadari telah menjadi bagian dari perilaku kaum muslim Indonesia bermula dari abad XIII-XX M.15

Metode yang dikedepankan dalam tulisan ini adalah metode historis dengan pendekatan juridis. Historis digunakan untuk menunjukkan perjalanan Islam memasuki dan mengalami perkembangan di wilayah Indonesia, sebagai sebuah alur sejarah. Metode juridis untuk menunjukkan legalitas dan legitimasi hukum Islam sebagai satu bagian yang tidak terpisah dari konteks memahami Islam dalam kerangka satu kesatuan (holistik). Spesifikasi tulisan ini menggunakan pendekatan penelitian kepustakaan atau yang lebih dikenal dengan library research.

\section{Pembahasan}

\section{Hukum Islam Periode Kerajaan Islam di Nusantara}

Era kesultanan atau kerajaan, merupakan era kejayaan Islam sebagai sebuah ajaran yang memiliki tempat dan pengaruh luas di wilayah Nusantara, setelah pengaruh keyakinan (kepercayaan) asli nusantara kemudian agama Hindu mewarnai sisi kehidupan bangsa Indonesia.

Aceh menjadi daerah pertama masuknya Islam ke Nusantara pada abad pertama Hijriah atau tujuh M dibuktikan dengan makam raja Samudera Pasai yang

\footnotetext{
${ }^{14}$ Bahder Johan Nasution, Sri Warjiyati, Hukum Perdata Islam (Kompetensi Peradilan Agama Tentang Perkawinan, Waris, Wasiat, Hibah, Wakaf, Dan Shodaqoh), Mandar Maju, Bandung, 1997, hlm. 2.

15 Makna disadari berkaitan dengan legalitas formalitas yang telah diatur melalui hukum positif di Indonesia, sedangkan tidak disadari belum diatur secara formil terhadap perilaku-perilaku keagamaan muslim Indonesia.
} 
dikenal dengan Malik as-Shaleh (Malikus Shaleh). ${ }^{16}$ Bukti catatan-catatan resmi dan Jurnal Cina pada periode Dinasti Tang 618 M secara ekplisit menegaskan bahwa Islam sudah masuk wilayah Timur jauh, yakni Cina dan sekitarnya pada abad pertama Hijriah melalui lintas laut dari bagian Barat Islam. Cina yang dimaksudkan pada abad pertama Hijriah tiada lain adalah gugusan pulau-pulau di Timur Jauh termasuk wilayah-wilayah Kepulauan Indonesia. ${ }^{17}$

Islam yang pertama kali masuk ke Aceh pada abad $7 \mathrm{M}$, banyak mempengaruhi adat-istiadat Aceh. Pengaruh ini dibuktikan dengan pepatah yang berbunyi: Hukom ngo Adat lagee Zat ngo Sipheuet (hukum dengan adat seperti benda dengan sifatnya, tidak terpisah). Hukum di sini diartikan dengan hukum Islam yang diajarkan oleh para ulama. Ini ditunjukkan oleh pepatah lain yang berbunyi: Adata bak Meureuhom, Hukum Bak Syiah Ulama. ${ }^{18}$

Hukum Islam pada era ini mulai mewarnai kehidupan bangsa Indonesia, dengan fiqih yang berasal dari jazirah Arab dalam menentukan segala tindakan umat Islam. Fiqih walaupun telah diakui sebagai lembaga yang mengatur kehidupan masyarakat pada saat itu tidak menjadikannya sebagai kekuatan utama dalam pergaulan antar masyarakat. Tasawuf dan amalan tarekat yang menjadi kegiatan utama dalam pergaulan, pemimpin-pemimpin atau para guru suluk (sjujuch al-turuq) mendapatkan pernghormatan dibandingkan ahli-ahli ilmu kalam (mutakallimun), maupun para ahli hukum (fuqaha). ${ }^{19}$

Perkembangan yang pesat dari ajaran Islam mulai mempengaruhi aspek kehidupan ketatanegaraan, pengaruh tersebut mulai menguat seiring dengan munculnya berbagai macam kerajaan atau kesultanan di wilayah Sumatera, sebagai pusat dari perkembangan kebudayaan Islam Melayu yang berhubungan

\footnotetext{
${ }^{16}$ Syamsul Bahri, Pelaksanaan Syari'at Islam Di Aceh Sebagai Bagian Wilayah Negara Kesatuan Republik Indonesia (NKRI), Jurnal Dinamika Hukum, Vol. 12 No. 2 Mei 2012, hlm. 360.

17 M. Yakub, Perkembangan Islam Indonesia, Kalam: Jurnal Studi Agama dan Pemikiran Islam, Volume 7, Nomor 1, Juni 2013, hlm. 138.

18 Ismuha, Islam Dan Masyarakat Aceh dalam Agama dan Perubahan Sosial, Rajawali, 1983. hlm. 5. Poteu Meureuhomdiartikan sebagai Sultan Iskandar Muda yang memiliki kedudukan sebagai pemimpin dan ulama dikarenakan kemampuannya dalam memimpin dan menguasai ilmu-ilmu islam (pen.)

${ }^{19}$ A. Mukti Ali, Alam Pikiran Islam Modern Di Indonesia dan Modern Islamic Thaought In Indonesia, Jajasan Nida, Jogjakarta, 1969, hlm. 5.
} 
langsung dengan kerajaan-kerajaan Islam di wilayah Fatani dan wilayah Mindanao, De la zur. Sekalipun secara etnologis penduduk di kawasan ini lebih homogen etnis Melayu, namun dalam kenyataan realitas sosial dan budayanya yang berkembang di dalamnya menunjukkan keragaman, atau heterogen. ${ }^{20}$

MB Hooker menunjukkan Islam Asia Tenggara secara umum berada di wilayah Malaysia, Indonesia dan Filipina Selatan ${ }^{21}$ yang telah memiliki peninggalan-peninggalan berupa naskah yang berisi tentang filsafat dan hukum, dalam pandangannya Islam melakukan akulturasi dengan budaya atau tradisi lokal yang berada di ketiga wilayah tersebut. Catatan yang muncul dari MB Hooker bahwa proses akulturasi tersebut tidak menghilangkan corak ajaran Islam yang mengedepankan pandangan akan kesatuan masyarakat Islam atau yang lebih dikenal dengan ummah. ${ }^{22}$

Pengaruh Islam di wilayah Asia Tenggara membentuk kristalisasi ajaran Islam yang berpedoman atau setidaknya dipengaruhi dengan kuat oleh satu masdzhab. Khusus bagi pengaruh madzhab Sayafi'i menjadi pedoman utama dalam memaknai Islam melalui bidang fiqih. Pengaruh yang kuat ini tidak hanya memberi corak yang khusus bagi masyarakat-masyarakat Nusantara pada masa lampau dalam melakukan berbagai kegiatan keagamaan. Sebagaimana diketahui tindakan atau perilaku keagamaan Islam dilatarbelakangi oleh kaidah-kaidah atau aturan-aturan yang telah ditetapkan melalui al-Quran dan al-Hadits ssebagai pedoman beragama. ${ }^{23}$

Pedoman beragama yang disampaikan melalui peran para pedagang dari Semenanjung Arabia tidak hanya mempengaruhi masyarakat, melainkan toko-

20 Lihat: Ajid Tohir, Studi Kawasan Dunia Islam Perspektif Etno-Linguistik dan Geo-Politik, Rajawali Press, Jakarta, 2011, hlm. 323.

${ }^{21}$ Konsep dan gagasan Amerika itu dituangkan dalam Philipine Bill tahun 1902, yang membagi wilayah Islam selatan menjadi lima bahagian : Zamboanga, Lanao, Cotabato, Davao dan Sulu, dan akan diperintah langsung oleh Amerika dari Manila. (Saifullah SA, Umat Islam Di Filipina Selatan Sejarah, Perjuangan Dan Rekonsiliasi, ISLAMICA, Vol. 3, No. 1, September 2008, hlm. 59).

22 MB Hooker, Introduction: Islamic Law in South-east Asia, Asian Law Journal Vol 4, 2002, hlm. 215. Naskah-naskah ini memiliki peran yang cukup besar terhadap informasi-informasi terkait dengan perilaku kehidupan di Indonesai, Malaysia dan Filipina Selatan, terutama dengan kehidupan keberagamaan termasuk di dalamnya terkait karakteristik hukum Islam di Asia Tenggaa.

${ }^{23}$ Lihat: Maimunah, Sistem Pendidikan Surau: Karakteristik, Isi Dan Literatur Keagamaan, TA'DIB, Vol. XVII, No. 02, Edisi Desember 2012. Lihat juga: Asep Ahmad Hidayat, Muslim Minoritas 
tokoh masyarakat yang di kemudian hari mendirikan kerajaan-kerajaan Islam di wilayah Nusantara, seperti Kerajaan Malaka, Kerajaan Samudera Pasai, Kerajaan Demak, Kerajaan Mataram Islam yang tidak hanya meliputi wilayah kekuasaan di Sumatera melainkan terus berkembang sampai ke wilayah Papua dengan adanya Kerajaan Islam Raja Ampat. ${ }^{24}$

Naruddin Ar-Raniri menulis buku Sirat al- Mustaqim pada tanggal $1628 \mathrm{M}$. Kitab yang dimaksud merupakan kitab pertama yang disebarluaskan ke seluruh wilayah Indonesia untuk menjadi pegangan umat Islam. Kitab ini di analisis oleh Syeikh Arsyad Al-Banjari yang kemudian diberikan komentar dalam suatu kitab yang diberi judul Sabil al-Muhtadin. Buku ini dijadikan pegangan dalam menyelesaikan sengketa antar umat Islam, di daerah Kesultanan Banjar. Demikian juga di daerah kesultanan Palembang dan Banten diterbitkan beberapa kitab hukum Islam yang dijadikan pegangan dalam masalah hukum keluarga dan warisan. Juga diikuti oleh kerajaan-kerajaan Demak, Jepara, Tuba, Gresik dan Ngumpul. ${ }^{25}$

Snouck Hurgronje, menyampaikan bahwa pengaruh madzhab ini diperkenalkan melalui pengajaran terhadap murid dengan pertama kalinya mempelajari bahasa Arab, yang dilanjutkan belajar dari kitab fikih aliran Syafi'i. Materi yang diajarkan adalah tentang kebersihan, ibadah, zakat, puasa, haji dan hukum pernikahan. Surau menjadi titik tolak pengaruh yang cukup kuat akan madzhab Syafi'i dalam perkembangan kehidupan beragama di Asia Tenggara. Daerah yang banyak menggunakannya adalah Minangkabau, Sumatera Selatan, Semenanjung Malaysia, dan Patani (Thailand Selatan). ${ }^{26}$

Fiqih yang berkembang pada saat penguasaan wilayah Melayu oleh Kesultanan Malaka dan Kesultanan Samudera Pasai adalah Fiqih madzhab Syafi'i, yang dengan terang dan tegas dinyatakan oleh Malik al-Zahir sebagai Sultan Samudera Pasai bahwa Pasai bermadzhab Syafi'i. Pengakuan ini memiliki

\footnotetext{
${ }^{24}$ Lihat: Muhammad Syarif, Teori-Teori Masuknya Islam ke Wilayah Timur Indonesia, Jurnal Fakultas Ilmu Budaya Universitas Indonesia, 2014, hlm. 11.

25 Sagaf S.Pettalongi, Local Wisdom dan Penetapan Hukum Islam di Indonesia, Jurnal Tsaqafah, Vol. 8, No. 2, Oktober 2012, hlm. 238.

${ }^{26}$ Maimunah, Sistem Pendidikan Surau : Karakteristik, Isi Dan Literatur Keagamaan, TA'DIB, Vol. XVII, No. 02, Edisi Desember 2012, hlm. 256, 26-, dan 261.
} 
pengaruh yang kuat terhadap berkembangnya madzhab Syafi'i di wilayah Asia Tenggara. ${ }^{27}$

Penguatan madzhab Syafi'i sebagai kaidah dalam menerapkan dan melaksanakan ritualitas keagamaan diperkuat melalui peran kekuasaan Kerajaan Samudera Pasai sebagai kerajaan Islam pertama. Sultan Malik As-Shaleh adalah ahli dalam bidang fikih menurut madzhab Syafi'i yang dengan bantuan para ulama dari berbagai mancanegara serta dari qadhi (hakim) sultan pertama dari kerajaan ini menerapkan berbagai keputusan-keputusan yang berkaitan dengan pelaksanaan hukum Islam di daerahnya. Salah satu bukti penerapan dan pelaksanaan hukum Islam di Samudera Pasai dapat ditemukan dalam Prasasti Trengganu. ${ }^{28}$

Madzhab Syafi'i yang menguat pada era Kesultanan Samudera Pasai mengalami perubahan dan perkembangan. Perjalanan waktu mengubah Islam melalui hukum yang terkandung di dalamnya dengan berbagai perubahanperubahan yang terkait dengan identitas Islam sebagai agama yang telah berbeda dengan ketika munculnya di Semenanjung Arabia. ${ }^{29}$ Perbedaan ini tidak dimaknai sebagai perbedaan dalam makna ke-Teologia-an, melainkan dipahami dalam pembentukan dan penerapan hukum yang sejalan dengan perubahan masa (zaman) dan masyarakat.

Mahsun lebih jauh mengungkapkan bahwa perubahan-perubahan yang muncul pada abad 17 dan $18 \mathrm{M}$ di Indonesia (dulu Nusantara), berada dalam koridor keseimbangan baru tasawwuf-fiqih, dan wacana Syafi"iyah. Hal ini terjadi karena pemikiran hukum merupakan paralelisme dari gerakan pemikiran tasawuf yang terlebih dahulu ada, dan akibat langsung dari keberadaan mazhab Syafi"i yang dianut oleh penyebar Islam pertama di Nusantara abad 12 dan 13 M. Dua

\footnotetext{
27 Syed Hamid bin Syed Jaafar Albar, The Role of Islamic Civilisation in Strengthening the Foreign Relations between Countries of ASEAN, Proceedings ASEAN Community Conference 2015, Published by Institute of Islam Hadhari Universiti Kebangsaan Malaysia together with Faculty of Human Ecology Universiti Putra Malaysia Selangor, hlm. 13.

28 Syed Hamid bin Syed Jaafar Albar, The Role of Islamic Civilisation in Strengthening the Foreign Relations between Countries of ASEAN, Proceedings ASEAN Community Conference 2015, Bangi, Malaysia, 11-12 November 2015, hlm. 12.

${ }^{29}$ Id., hlm. 13.
} 
karakteristik epistemologi inilah yang menjadi langgam menonjol bagi gerakan pemikiran hukum Islam Indonesia ketika itu. Tidak adanya karya yang bisa dibilang otentik dan originil yang terlahir dari para pemikir (ulama) di Indonesia, juga lebih disebabkan situasi yang kurang menguntungkan dari proses, waktu, dan karakter Islam pertama di Indonesia tersebut. ${ }^{30}$

Ali Yafie mengungkapkan bahwa konsep fikih Syafi'i banyak berjasa dalam membentuk kesadaran hukum bagi masyarakat muslim Indonesia walaupun tidak merupakan bagian hukum yang tertulis, namun ia telah menjadi hukum yang hidup (the living law) di tengah-tengah masyarakat muslim Indonesia. Sehingga sekalipun hukum-hukum yang berasal dari fikih Syafi'i tersebut belum merupakan hukum tertulis (undang-undang), tetapi dalam penerapannya telah jauh berkembang dalam yurisprudensi, kebiasaan dan pendapat umum di masyarakat. ${ }^{31}$

Pandangan Ali Yafie sebagai seseorang yang memiliki kematangan dalam memahami Islam beserta ajaran yang terkandung dalamnya, melalui pemahaman Ahmad Gunaryo diperdalam kembali dengan keterkaitan politik dengan hukum Islam yang dalam pandangan Ahmad Gunaryo telah terjadi percampuran yang lekat, erat dan kental dalam menunjukkan hukum Islam yang telah dibangun dan terbangun berabad-abad yang lampau melalui peran kerajaan-kerajaan Islam di abad 13-17 M yang tidak bisa dilepaskan dari pemahaman yang sesuai dengan budaya. ${ }^{32}$

\footnotetext{
${ }^{30}$ Mahsun, Genesis Pemikiran Hukum Islam Nusantara (Studi Pengaruh Islam Pertama Terhadap Perkembangan Pemikiran Dan Politik Hukum Islam Nusantara Klasik). al-Mabsut Vol. 9, No. 1 2015, hlm. 14.

${ }^{31}$ Ali Yafie, Menggagas Fiqh Sosial, Mizan, Bandung, 1994, hlm. 50.

32 M. Shohibul Imam, Hukum Islam Dalam Pergumulan Politik Hukum Nasional Era Reformasi, AlTahrir, Vol. 13, No. 2 November 2013, hlm. 279.Penyesuaian hukum Islam dengan ragam budaya merupakan kalimat yang dapat mengakomodir sebagai salah satu sarana untuk membangun rekonsiliasi hukum yang akomodatif terhadap dinamika hukum Islam sehingga melalui rekonsiliasi hukum Islam dengan hukum nasional tersebut dapat terbentuk hukum nasional yang sesungguhnya.
} 


\section{Hukum Islam Periode VOC dan Pemerintah Belanda}

Syari'at Islam sejak kedatangannya ke Nusantara hingga saat ini merupakan hukum yang hidup (living law), tidak hanya pada tataran simbol, melainkan juga pada tataran praktis. Hal tersebut bukan semata-semata sebuah tanda bahwa mayoritas pemeluk agama di Indonesia adalah agama Islam, melainkan syari'at Islam dalam realitas alaminya di beberapa daerah sudah menjadi tradisi (adat) yang terkadang dianggap sakral. Secara sosiologis dan kultural, syari'at Islam merupakan hukum yang berurat dan berakar dalam budaya masyarakat. Hal ini disebabkan fleksibilitas dan elastisitas yang dimiliki syari'at Islam. Artinya meskipun ada kekuatan otonom yang terdapat dalam ketetapan Tuhan, namun syari'at Islam dalam realisasinya mampu melakukan upaya transformative-adaptif. 33

Transformatif-adaptif menuntut hukum Islam selalu berada dalam keadaan ikut serta melebur dengan realitas yang terjadi sebagai representasi pemaknaan rahmatan lil 'alamin. Formulasi kata ini berlaku pula terhadap perubahan yang terjadi dalam wilayah Nusantara melalui sumbangsih Kerajaan-Kerajaan Islam abad 14-18 M. Perubahan yang terjadi setelah abad $18 \mathrm{M}$ mempengaruhi pula hukum Islam dalam berbagai aspek yang terdapat di dalamnya, baik itu dalam pembentukan, penyusunan maupun penerapan. ${ }^{34}$

Transformatif-adaptif hukum Islam semakin terlihat bila dilihat melalui kenyataan perubahan kekuasaan yang dahulu dimiliki otoritas Kesultanan (Sultan/Qadhi). Kekuasaan dan beralih dari kerajaan-kerajaan Islam kepada serikat/kongsi Dagang yang bernama V.O.C. Peran V.O.C (Vereenigde Oostindische Compagnie) yang merupakan lembaga kolonial era pertengahan menunjukkan keadaan Islam semakin berada pada kedudukan yang tidak terlalu dominan dalam

\footnotetext{
33 Sirajuddin M, Wacana Penerapan Hukum Islam dalam Tinjauan Politik Hukum Nasional, SosioReligia, Vol. 8, No. 3, Mei 2009, hlm.809.

${ }^{34}$ Lihat: Chamim Tohari, Fiqh Keindonesiaan: Transformasi Hukum Islam Dalam Sistem Tata Hukum Di Indonesia, ANALISIS: Jurnal Studi Keislaman, Volume 15, Nomor 2, Desember 2015.
} 
menentukan perilaku atau tindakan-tindakan yang dilakukan oleh masyarakat Nusantara layaknya sebelum abad $18 \mathrm{M}^{35}$

Dominasi V.O.C tidak serta merta menghilangkan hukum Islam sebagai aturan perilaku yang dianut dan dilaksanakan oleh umat Islam pada saat itu. Alasan mendasar bagi pemberlakuan hukum Islam oleh V.O.C muncul akibat ketidakmampuan masyarakat Indonesia untuk memahami berbagai macam aturan hukum yang dibentuk, disusun dan diterapkan oleh V.O.C. Alasan ini menyebabkan V.O.C sebagai sebuah Kongsi Dagang yang menguasai berbagai jalur perdagangan di Nusantara memberikan keleluasaan bagi masyarakat Indonesia untuk menerapkan aturan hukum secara mandiri, dengan tidak menyalahi aturanaturan sebagai berikut: Pertama, Statuta Batavia yang ditetapkan pada tahun 1642 oleh V.O.C, menyatakan bahwa hukum kewarisan Islam berlaku bagi para pemeluk agama Islam. Kedua, kompilasi hukum kekeluargaan Islam dikenal dengan nama Compendium Freijer. 36

Peran kolonial melalui V.O.C yang diakui bukan sebagai penjajah, melainkan hanya sebagai sebuah organisasi perniagaan (perdagangan) terus berlanjut sampai tahun 1799, sebagai masa atau waktu kebangkrutan yang dialami oleh V.O.C. Keadaan ini mengawali peran aktif Pemerintah Belanda untuk mengambil-alih semua hutang V.O.C, serta mulai berkuasa di Hindia-Belanda. ${ }^{37}$

Salah satu aspek kehidupan yang menjadi penting untuk dialihkan penguasaanya berkaitan dengan penerapan hukum yang berlaku di wilayah Indonesia. Perjalanan waktu yang diberikan melalui pengalaman kolonialisme V.O.C menuntun dan menuntut Pemerintah Kolonial Belanda melakukan perubahan cara dalam mendekatkan diri, dan merangkul umat Islam serta

\footnotetext{
35 Mahsun, Genesis Pemikiran Hukum Islam Nusantara (Studi Pengaruh Islam Pertama Terhadap Perkembangan Pemikiran Dan Politik Hukum Islam Nusantara Klasik). al-Mabsut Vol. 9, No. 1 2015

36 Sirojul Munir, Pengaruh Hukum Islam Terhadap Politik Hukum Indonesia, Jurnal Istinbath Vol. 13, No.2, Desember 2014, hlm. 135-136.

37 Kees De Jong, Dari Perpisahan Kolonial Ke Perjuangan Nasional Bersama Sejarah Singkat Hubungan Islam-Kristen Di Indonesia ( $\pm 1520-1949)$, Gema Teologi Vol. 36, No. 2, Oktober 2012, hlm. 239.
} 
masyarakat yang memegang teguh adat dan budaya yang telah lama menjadi bagian kearifan lokal wilayah Nusantara.

Kebangkrutan V.O.C menandai kemunculan Pemerintah Kolonial Belanda untuk melanjutkan kolonialisme di bumi Nusantara. Peralihan kekuasaan dari V.O.C sebagai Kongsi Dagang yang menguasai wilayah Indonesia melalui bidang ekonomi dengan eksploitasi perdagangan rempah-rempah ke daratan Eropa, berubah menjadi kolonialisme di berbagai bidang kehidupan bangsa Indonesia yang telah mendiami wilayah Nusantara ini jauh sebelum Pemerintah Kolonial Belanda menguasai Indonesia dan wilayah perairannya. ${ }^{38}$

Kebangkrutan yang dialami oleh V.O.C tidak menghilangkan jejak yang menandai di Nusantara (Indonesia) pernah muncul organisasi yang mengatur Nusantara setelah berkurangnya pengaruh Kerajaan-Kerajaan Islam. Receptio in complexu kemudian menjadi dasar hukum dalam Regeering Reglemen (RR) tahun 1885.39 Pasal 75 ayat (3) RR menegaskan bahwa bagi Bumi putera diberlakukan hukum agama. Keputusan politik (politik hukum) yang dianut itu merupakan pengaruh teori yang dikembangkan oleh Lodewijk Willem Christian van den Berg. $^{40}$

Teori van den Berg menempatkan Islam menjadi salah satu hukum yang berlaku di Indonesia sebelum diterbitkan atau mendapatkan legitimasi melalui pendekatan formalitas dengan RR, didahului oleh Keputusan Raja Belanda (Koninkelijk Besluit No. 19 tanggal 24 Januari 1882) yang kemudian diumumkan dalam Staatblad No. 152 Tahun $1882 .^{41}$

Teori yang dikembangkan Van den Berg mengarahkan hukum Isalm tetap menjadi salah satu hukum, yang memiliki peranan besar dalam menyelesaikan berbagai permasalahan yang terdapat dalam masyarakat muslim era pra

\footnotetext{
${ }^{38}$ Lihat: A. Kardiyat Wiharyanto, Pergantian Kekuasaan Di Indonesia Tahun 1800, SPPS Vol. 21, No. 1, April 2007.

${ }^{39}$ Lihat: Ismail Suny, Kedudukan Hukum Islam dalam Sistem Ketatanegaraan Indonesia, dalam Hukum Islam di Indonesia Perkembangan dan Pembentukannya, Rosdakarya, Bandung, 1991, hlm. 73-75.

40 Zainal Arifin Hoesein, Pembentukan Hukum Dalam Perspektif Pembaruan, Volume 1 Nomor 3, Desember 2012, hlm. 321.

${ }^{41}$ A. Wasit Aulawi, Sejarah Perkembangan Hukum Islam, dalam Dimensi Hukum Islam Dalam Sistem Hukum Nasional, Gema Insani Press, Bandung, 1996, hlm. 55.
} 
kemerdekaan. Teori receptio in complexu menempatkan Islam dengan hukumnya yang tetap memiliki peran, sebagai salah satu contoh adalah penggunaan kitab Mugharrar dan Pepakem Cirebon serta peraturan yang dibuat oleh B. J. D. Cloowijk untuk diberlakukan di wilayah Kerajaan Bone dan Gowa, Sulawesi Selatan. ${ }^{42}$

Upaya-upaya yang muncul sebagai cara pendekatan baru dari Pemerintah Kolonial Belanda diwujudkan melalui teori receptie yaitu hukum yang berlaku dalam realita masyarakat adalah hukum adat, sedangkan hukum Islam dapat diberlakukan apabila telah beradaptasi dengan hukum adat. teori ini dilegalisasi dalam undang-undang dasar Hindia Belanda, sebagai pengganti RR yaitu Wet op de Staatsinrichting van Nederlands Indie (IS). Pengaruh dari perubahan RR ke IS menyebabkan dicabutnya hukum Islam dari lingkungan tata hukum Hindia Belanda melalui Staatsblad No. 212 Tahun 1929.43

Penganut teori receptie mengemukakan pendapat bahwa terdapat sebagian kecil hukum Islam yang mempengaruhi hukum adat. Pengaruh yang kecil terhadap hukum adat tidak menyebabkan hukum tersebut merupakan hukum Islam, tetapi tetap dikatakan sebagai adat dikarenakan pengaruhnya tidak menyebabkan berubahnya hukum adat secara keseluruhan. ${ }^{44}$

Ter Haar mengungkapkan antara hukum adat, dan hukum Islam tidak mungkin bersatu, apalagi bekerjasama, karena titik tolaknya berbeda. Hukum adat bertitik tolak dari kenyataan hukum dalam masyarakat, sedang hukum Islam bertitik tolak dari kitab-kitab hukum (hasil penalaran manusia). Titik tolak tersebut menghadirkan perbedaan dan tidak sedikit memunculkan pertentangan, sekalipun dapat diperlunak tetapi sering kali tidak. Dasar ini yang menjadi munculnya pembatasan terhadap kewenangan untuk mengadili perkara di Pengadilan Jawa dan Madura hanya terkait untuk bidang-bidang tertentu saja. ${ }^{45}$

Perubahan yang terjadi dengan munculnya teori receptie dengan penguatan legalitas formal melalui IS tidak terlepas dari peran Christian Snouck

42 Zainuddin Ali, Hukum Islam, Sinar Grafika Jakarta, 2006, hlm. 81.

43 Lihat:. Abdul Manan, Masalah Hukum Perdata Islam di Indonesia, Kencana, Jakarta, 2006, hlm.11.

44 Sajuti Thalib, Receptio In Complexu, Theorie Receptie Dan Receptio A Contrario, dalam

Pembaharuan Hukum Islam di Indonesia, Yayasan Penerbit Universitas Indonesia, Jakarta, 1976, hlm. 46.

45 Muhammad Daud Ali, Hukum Islam, Rajawali Pers, Jakarta, 1998, hlm. 203. 
Hurgronje (1857-1936 M), yang menekankan pentingnya teori receptie dengan maksud tidak hanya berupaya mendekatkan diri dengan Islam dan masyarakat adat, melainkan memiliki tujuan untuk menekan pengaruh Islam terhadap masyarakat Indonesia. Christian Snouck Hurgronje memiliki pengaruh yang kuat terhadap keberlakuan teori receptie didorong oleh jabatan dirinya sebagai penasihat Pemerintah Kolonial Belanda dalam kaitannya dengan Islam dan persoalan-persoalan pribumi. Snouck Hurgronje mendalami hukum dan agama Islam secara khusus di Indonesia. ${ }^{46}$

Pandangan yang muncul dari Christian Snouck Hurgronje merupakan pendalaman agama Islam yang telah dipelajari oleh dirinya ketika menuntut ilmu di Leiden, dengan penguasaan Bahasa Arab. ${ }^{47}$ Pandangan-pandangannya dalam teori receptie memberikan argumentasi dan dasar bagi Belanda untuk membentuk sebuah komisi yang bertugas meninjau kembali wewenang Peradilan Agama di Jawa dan Madura. Dengan bekal sebuah rekomendasi dari komisi ini, lahirlah Stb (staatblad) Nomor 116 Tahun 1937 berisi pencabutan wewenang Peradilan Agama untuk menangani masalah waris dan yang lainnya, perkara perkara ini kemudian dilimpahkan kepada Landraad (Pengadilan Negeri). ${ }^{48}$

\section{Hukum Islam Era Kemerdekaan}

17 Agustus 1945 merupakan puncak dan pusat dari perubahan kehidupan Bangsa Indonesia, perubahan yang tidak hanya berada pada satu titik yaitu pelepasan diri dari kolonialisme yang telah berlangsung jauh sebelum Nusantara dikenal dengan nama Indonesia sebagaimana yang tertera dalam teks proklamasi. Perubahan yang dilatarbelakangi peristiwa pernyataan deklarasi atas kemerdekaan mengubah berbagai aspek kehidupan masyarakat Indonesia seperti ekonomi, budaya, sosial-kemasyarakatan, keberagamaan, politik dan bagian yang

\footnotetext{
46 Moh. Idris Ramulto, Asas-Asas Hukum Islam (Sejarah Timbul dan Berkembangnya Kedududukan Hukum Islam dalam Sistem Hukum Indonesia), Sinar Grafika, Jakarta, 1995, hlm.

56.Pengetahuan akan Indonesia dan Islam diperoleh dirinya ketika melakukan penyamaran sebagai dokter mata dengan nama Abdul Ghafur di Mekkah.

${ }^{47}$ Lihat: H.M. Rosjidi, Snouck Hurgronje Seorang Pelopor dalam Mempelajari Islam, dalam A. Adaby Darban, Snouck Hurgronje dan Islam di Indonesia, tp., Yogyakarta: tt.. hlm. 1

48 A. Qadri Azizy, Eklektisisme Hukum Nasional, Gama Media, Yogyakarta, 2002, hlm. 155.
} 
tidak dapat dipisahkan adalah aspek hukum sebagai penyatu dari aspek-aspek tersebut. 49

Perubahan yang bermuara pada Proklamasi Indonesia tidak serta merta menempatkan Islam dan negara pada pandangan yang satu atau lebih dikenal dengan syari'at dan negara. Ketegangan antara dua entitas ini, dikarenakan memiliki dua tataran penting yang berbeda. Perbedaan ini muncul dari pandangan Soekarno pada tataran scholastik atau bersifat teoritik-idealistik, dan pandangan yang muncul dari M. Natsir berupa realisticpolitik atau ideologis-empirik yang muncul ke permukaan pada akhir tahun 1930-an.50

Periode kemerdekaan Indonesia mendorong Islam sebagai ajaran transformatif adatif ditunjukkan dengan munculnya berbagai pandangan fiqih Indonesia yang tidak tercerabut dari akarnya tetapi membumi dalam keterlaksanaan terhadap Muslim Indonesia. Contoh fiqih Indonesia atau fiqih keIndonesia-an diungkapkan oleh Hazairin dengan menempatkan Islam sebagai ajaran agama yang bersinergi bersama masyarakat yang didatanginya. Pemikiran Hazairin membentuk bahwa hukum Islam tidak hanya terkait dengan apa yang terdapat dalam al-Quran maupun al-Hadits, melainkan di dalamnya terdapat unsur-unsur kemasyarakatan yang cenderung dengan penguatan al-ahkam alkhamsah yang berorientasi kepada maslahah mursalah atau kaidah yang menunjukkan suatu aturan hukum dapat mengalami penurunan tingkat dari yang sebelumnya menunjukkan pelarangan secara mutlak (haram) menjadi boleh $(\text { mubah, mandub })^{51}$

Teori lainnya yang muncul dari pemikiran Hazairin adalah terkait dengan sistem kewarisan bilateral yang muncul melalui pendekatan antropologi sosial

\footnotetext{
${ }^{49}$ Hukum sebagai penyatu dari berbagai aspek kehidupan bangsa Indonesia yang dipengaruhi oleh Proklamasi Indonesia 17 Agustus 1945 tidak mungkin dapat berdiri sendiri tanpa diringi secara bersama-sama oleh aspek Ekonomi, budaya, sosial-kemasyarakatan, keberagamaan, politik yang dirangkum sebagai sebuah Filsafat yang dinamai Filsafat Pancasila. Lihat: Soediman Kartohadiprodjo, Beberapa Pemikiran Sekitar Pancasila, Alumni, Bandung, 1980, hlm. 62.

50 Abdul Halim, Membangun Teori Politik Hukum Islam Di Indonesia, Jurnal Ahkam, Vol. XIII, No. 2, Juli 2013, hlm. 260.

51 Bismar Siregar, Prof. Mr. Dr. Hazairin Seorang Mujahidin Penegak Hukum Berdasar Ke -Tuhanan Yang Maha Esa, dalam Pembaharuan Hukum Islam di Indonesia, Yayasan Penerbit Universitas Indonesia, Jakarta, 1976, hlm. 11.
} 
Indonesia. Pendekatan ini mengarahkan kepada munculnya bagian ahli waris dzawul qarabat atau bagian yang ditentukan berdasarkan kedekatan kekerabatan dengan pewaris setelah harta waris dibagi kepada ashab al-furudh. Sistem bilateral kewarisan Hazairin menghilangkan konsepsi 'ashabah dan dzaw alarham yang menjadi konsepsi hukum waris Islam dalam madzhab ahlu sunnah wa al-jama'ah. ${ }^{52}$

Hasbi ash-Shiddieqy memiliki pandangan yang berbeda terhadap munculnya dzawul qarabat dalam sistem kewarisan bilateral Hazairin. Hasbi ashShiddieqy tetap mempertahankan pembagian ahli waris sesuai dengan apa yang termaktub dalam al-Quran dan al-Hadits melalui metode atau atsar-atsar yang muncul dari pandangan jumhur (mayoritas) ulama madzhab ahlu sunnah wa aljama'ah. Ringkasnya Hasbi ash-Shiddieqy tidak mengenal pembagian waris dengan sistem dzawul qarabat, melainkan tetap menggunakan ashabah dan dzaw al-arham..$^{53}$

Hazairin yang mengedepankan konsep maslahah mursalah dengan pendekatan antropologi sosial Indonesia, tidak memiliki perbedaan yang jauh dengan fiqih sosial milik Sahal Mahfudz, dengan tambahan maqashid al-syariah dalam memetakan hukum Islam di Indonesia. Sahal Mahfudz, menyampaikan kitab fiqih harus disikapi melalui pendekatan metodologis proporsional, sehingga tidak kehilangan maksud dan tujuan ajaran Islam dalam fiqih. Fiqih harus disikapi konstekstual, dengan tidak menghilangkan sisi tekstualitas yang terkandung di dalamnya. Metode kontekstual ini adalah metode (bermadzhab) yang harus dikembangkan, karena fiqih mengandung makna penalaran (reasoning) atas persoalan-persoalan hukum. Metode ini muncul dengan menangkap ungkapan Imam Ghazali yaitu seorang ulama harus menangkap "pesan zaman" demi kemaslahatan umat. ${ }^{54}$

\footnotetext{
52 Anwar Harjono, Hukum Kewarisan Bilateral Menurut al-Quran (Komentar Singkat Atas Teori Prof, Hazairi), dalam Pembaharuan Hukum Islam di Indonesia, Yayasan Penerbit Universitas Indonesia, Jakarta, 1976, hlm. 62.

${ }^{53}$ Lihat, T. M. Hasbi ash-Shiddieqy, Fiqhul Mawaris, Hukum-Hukum Warisan Dalam Syariat Islam, Bulan Bintang, Jakarta, 1973.

54 Sahal Mahfudz, Nuansa Fikih Sosial, LKiS, Yogyakarat, 1994, hlm. 71
} 
Puncak dari pemikiran Hazairin terkait hukum Islam sebagai konsep keagamaan yang transformatif adaptif adalah dengan munculnya teori receptie exit bahwa tidak benar Hukum Islam itu bergantung kepada hukum Adat, karena hukum Islam itu adalah mandiri, teori ini bertujuan untuk membantah teori receptie Snouck di atas. Hazairin, mengungkapkan hukum Islam adalah hukum yang mandiri dan lepas dari pengaruh hukum lainnya. ${ }^{55}$ Pemahaman terhadap teori receptie exit mendorong atau menjadi dasar bagi terbentuknya Piagam Jakarta (Jakarta Charter) pada tanggal 22 juni 1945. Piagam ini lahir dari hasil kompromi antara kelompok Islam dan kebangsaan (sekuler). ${ }^{56}$

Perubahan cara pandang hukum Islam yang dilandasi oleh teori receptie complexu dan receptie, tidak hanya muncul dari Hazairin melainkan pula muncul dari Sayuti Thalib yaitu dengan lahirnya teori receptio a contrario. Teori ini merupakan pengembangan teori receptie exit Hazairin. Teori receptio a contrario menyatakan pendapat yang sama sekali berlawanan arah dengan teori receptie Christian Snouck Hurgronje. Teori ini menunjukkan sebenarnya hukum adat berada di bawah hukum Islam dan harus sejiwa dengan hukum Islam, sehingga hukum adat baru dapat berlaku jika telah dilegalisasi oleh hukum Islam. Sayuti Thalib menyatakan bahwa dalam hukum perkawinan dan kewarisan bagi umat Islam berlaku hukum Islam. Hal ini sesuai dengan keyakinan, cita-cita hukum, dan cita-cita moralnya, yakni teori ini mengemukakan bahwa hukum adat bisa berlaku bagi orang Islam Manakala tidak bertentangan dengan hukum Islam. ${ }^{57}$

Salah satu contoh dari teori ini adalah antara lain: Suku Kaili di Sulawesi Tengah sebelum beragama Islam. Jika seorang laki-laki hendak menikah dengan seorang perempuan, maka disampaikan terlebih dahulu pada ketua dewan adat. Kemudian dewan adat akan mengambil air bersih dari sumber mata air, selanjutnya air tersebut secara hukum adat dipercikan oleh ketua dewan adat

\footnotetext{
55 Murdan, Pluralisme Hukum (Adat Dan Islam) Di Indonesia, Mahkamah, Vol. 1, No. 1, Juni 2016, hlm. 51..

56 Lihat: Muhammad Yamin, Naskah Persiapan Undang-Undang Dasar 1945, Yayasan Prapanca, Jakarta, 1959, hlm. 279.

57 Khoiruddin Buzama, Pemberlakuan Teori-Teori Hukum Islam Di Indonesia, AL-'ADALAH Vol. X, No. 4 Juli 2012, hlm. 470.
} 
kepada kedua calon mempelai, dan hal ini menandai selesainya pernikahan. Tetapi sesudah suku Kaili Sulawesi Tengah memeluk Islam, tata cara perkawinan seperti itu selanjutnya dilaksanakan oleh kedua calon mempelai sesuai hukum perkawinan Islam. ${ }^{58}$

Lazimnya sebuah teori yang berakar dari cara berfikir logis, teori yang muncul dari Hazairin dan Sayuti Thalib, dikembangkan kembali oleh Ichtijanto dengan teori Eksistensi. Teori Eksistensi menerangkan adanya hukum Islam dan hukum Nasional Indonesia, ${ }^{59}$ diantaranya:

a. Ada dalam arti sebagai bagian integral dari hukum nasional Indonesia.

b. Ada dalam arti adanya dengan kemandirian yang diakui adanya dan kekuatan serta wibawanya oleh kaum nasional dan diberi status hukum nasional.

c. Ada dalam hukum nasional dalam arti norma-norma hukum Islam yang berfungsi sebagai penyaring bahan-bahan hukum nasional Indonesia.

d. Ada dalam arti sebagai bahan utama dan unsur utama hukum nasional Indonesia. ${ }^{60}$

Fase munculnya Orde Baru sebagai peralihan kekuasaan dari Orde Lama membawa keinginan dan harapan umat Islam untuk mengembangkan dan mentransformasikan nilai-nilai hukum Islam ke dalam produk perundangundangan pada masa ini. Keinginan dan harapan ini tampaknya tidak sejalan dengan strategi pembangunan penguasa pemerintahan Orde Baru. Pada masa ini peranan partai-partai politik dimarginalkan, termasuk pembicaraan tentang masalah-masalah yang berkaitan dengan ideologi (selain Pancasila) ditabukan, terutama ideologi-ideologi yang bersifat keagamaan. ${ }^{61}$

\footnotetext{
58 Zainuddin Ali, Islam Tekstual dan Kontekstual: Suatu Kajian Akidah, Syariah dan Akhlak, Yayasan Al-Ahkam, Makassar, 1998, hlm. 9.

${ }^{59}$ Lihat, Cik Hasan Bisri, Hukum Islam di Indonesia, Pengembangan dan Pembentukan, Rosda Karya, Bandung, 1991, hlm. 137

60 Ichtijanto.. Pengembangan Teori Berlakunya Hukum Islam di Indonesia, dalam Tjun Surjaman (ed.). Hukum Islam di Indonesia: Perkembangan dan Pembentukan, Remaja Rosdakarya, Bandung, hlm. 137. Lihat juga: Ahmad Khumaidi Ja'far, Teori-Teori Pemberlakuan Hukum Islam Di Indonesia, Asas, Vol. 4, No. 2, Juni 2012.

61 EMK. Alidar, Hukum Islam Di Indonesia Pada Masa Orde Baru (1966-1997), Legitimasi, Vol.1 No. 2, Januari-Juni 2012, hlm. 239.
} 
Perubahan cara pandang Orde Baru mulai terlihat sejak tahun 1970-an sampai sekarang. Arah dinamika hukum Islam dan proses transformasi hukum Islam telah berjalan sinergis searah dengan dinamika politik di Indonesia. Tiga fase hubungan antara Islam dan negara pada masa Orde Baru yakni fase antagonistik yang bernuansa konflik, fase resiprokal kritis yang bernuansa strukturalisasi Islam, dan fase akomodatif yang bernuansa harmonisasi Islam dan negara. ${ }^{62}$

Fase akomodatif yang memunculkan nuansa harmonisasi Islam dan Pancasila, terkait dengan wilayah ketatanegaraan diungkapkan secara menarik oleh Achmad Siddiq. Achmad Siddiq menyampaikan Islam dan Pancasila merupakan dua hal yang berbeda, sehingga format yang disamakan dalam bentuk ideologi adalah Pancasila dan Piagam Madinah. Islam tidak dapat disamakan dengan Pancasila, karena bersumber dan merupakan ciptaan Tuhan, sedangkan Pancasila merupakan ideologi yang lebih banyak menggunakan kemampuan berfikir (nalar), sehingga keduanya memiliki kedudukan yang berbeda dalam diri manusia. Achmad Siddiq menegaskan dilarang untuk mencampuradukkan Pancasila dengan agama. Pancasila yang duniawi jangan di agama-kan dan agama yang berdasarkan pada wahyu jangan di Pancasila -kan. ${ }^{63}$

Pandangan yang mendukung Islam dan Ke-Indonesia-an ditunjukkan oleh Munawir Sjadazali, dengan menempatkan Islam tidak menolak terhadap munculnya ideologi Bangsa dan Negara yang berbeda dengan format negara Islam yang lazim digunakan di wilayah Timur Tengah. Islam dalam pandangan Munawir Sjadzali memberikan keleluasaan bagi manusia untuk menentukan dasa-dasar negara sebagai pedoman ketetatanegaraan suatu bangsa, walapun berbeda secara nama tetapi memiliki persamaan secara nilai yaitu nilai yang terkandung dalam

\footnotetext{
62 Muslim, Perkembangan Studi Hukum Islam Di Indonesia, al-'Adalah Vol. XI, No. 1 Januari 2013, hlm. 129.

${ }^{63}$ Andree Feillard, NU vis a vis Negara Pencarian Isi Bentuk dan Makna, LKiS, Yogyakarta, 2008, hlm. 12.
} 
Pancasila selaras dengan apa yang menjadi tujuan Islam menjadi rahmatan lilamin. $^{64}$

Harmonisasi Islam dan negara merupakan bagian dari transformasi hukum Islam dalam bentuk perundang-undangan (Takhrij al- Ahkâm fî al-Nash al-Qânun) sebagai produk interaksi antar elite politik Islam (para ulama, tokoh ormas, pejabat agama dan cendekiawan muslim) dengan elite kekuasaan (the rulling elite) yakni kalangan politisi dan pejabat negara. Sebagai contoh, diundangkannya UU No.1/1974 tentang Perkawinan. Peranan elite Islam cukup dominan dalam melakukan pendekatan dengan kalangan elite di tingkat legislatif, sehingga RUU Perkawinan No.1/1974 dapat diberlakukan.65

Pada saat Rancangan Undang-Undang Perkawinan diajukan oleh pemerintah ke DPR untuk dibahas sampai dengan terbit menjadi Undang-Undang bentuk hubungan politik pemerintah dengan umat Islam adalah pada posisi tidak harmonis. Sekitar tahun 1968 hubungan politik antara pemerintah dan umat Islam telah menunjukkan dengan jelas adanya suatu ketegangan, yaitu dengan terbitnya Inpres No 13 Tahun 1968 yang menutup perdebatan tentang dasar negara. Gerakan politik Islam bisa ditekan atau dimarginalkan. Maka sejak itulah hubungan umat Islam dengan pemerintah menjadi tegang, jika tidak boleh dikatakan bermusuhan. ${ }^{66}$

Tranformasi hukum Islam era kemerdekaan tidak hanya terlihat dan/atau ditampakkan melalui pengesahan Rancangan Undang-Undang No. 1 Tahun 1974 Tentang Perkawinan, menjadi Undang-Undang. Persetujuan oleh Dewan Perwakilan Rakyat (DPR) RI terhadap Undang-undang Pengadilan Agama yaitu UU No. 7 Tahun 1989 merupakan contoh lain, negara sebagai pemegang

\footnotetext{
${ }^{64}$ Lihat: Munawir Sjadzali, Islam Dan Tata Negara (ajaran, sejarah dan pemikiran), UI-Press, Jakarta, 1990.

65 Aden Rosadi, Legislasi Dan Politik Hukum Islam Di Indonesia, Seminar Nasional Tentang Legislasi dan Politik Hukum di Indonesia, STAIN Jurai Siwo Metro, 31 Mei 2016, hlm. 5. Lihat juga: Amak F.Z., Proses Undang-undang Perkawinan, Al-Ma'arif, Bandung, 1976, hIm. 35-48

${ }^{66}$ Kamsi, Politik Hukum Islam pada Masa Orde Baru, Ishraqi, Vol. 10, No. 1, Juni 2012, hlm. 7.
} 
kekuasaan tertinggi memiliki tugas untuk mengakomodir berbagai kepentingan yang terdapat dalam masyarakat. 67

Penolakan terhadap legalisasi Peradilan Agama pada masa itu masih gencar. Hal ini nampak pada pembahasan RUU No. 7 tahun 1989 tentang Peradilan Agama oleh DPR. Sebagian masyarakat, kebanyakan dari unsur agama Katolik menuduh bahwa penegakkan RUU tersebut berarti penegakkan kembali Piagam Jakarta. S. Wijoyo misalnya secara terang terangan mengatakan bahwa RUU tersebut menentang kesaktian Pancasila. Sedangkan R. Suprapto menyatakan bahwa keberadaan Peradilan Agama tidak dapat diterima karena penerimaan Peradilan Agama sama dengan menerima sumber di luar UUD 1945 dan Pancasila. Selain itu dia juga mengusulkan agar UU No. 14 tahun 1970 ditinjau kembali. ${ }^{68}$

Pembentukan Peradilan Agama, tidak hanya terbentur dengan kelompok yang menolak munculnya legalisasi Peradilan Agama, melainkan muncul pula perdebatan mengenai penyelesaian-penyelesaian terkait perkara-perkara yang memerlukan putusan yang memiliki keseragaman dalam menentukan hukum yang akan diberikan kepada para pihak yang berperkara di lembaga Peradilan Agama. Perdebatan mengenai hukum yang akan digunakan dikarenakan pada lingkungan peradilan agama sendiri, ada 13 buah kitab fikih bermazhab Syafi'i sebagai sumber hukum materiil untuk menyelesaikan perkara yang diajukan ke Pengadilan Agama. 69

Titik temu dalam menyelesaikan permasalahan yang bermula dari perdebatan mengenai sumber hukum materiil ditengahi dengan kemunculan

\footnotetext{
${ }^{67}$ Sirojul Munir, Pengaruh Hukum Islam Terhadap Politik Hukum Indonesia, Vol. 13, No.2, Desember 2014, hlm. 148-149.

${ }^{68}$ Ari Wibowo, Perkembangan Eksistensi Peradilan Agama di Indonesia Menuju ke Peradilan Satu Atap, Al-Mawarid Edisi XVII Tahun 2007, hlm. 134.

69 lihat Surat Edaran Biro Peradilan Agama tanggal 18 Februari 1958 Nomor B/I/735. 13 buah kitab fiqih tersebut adalah: Al-Bajuri, Fath al-Mu'in, Syarqawi 'ala al-Tahrir, Qalyubi/Muhalla, Fath al-Wahhab, Tuhfah, Targhib al-Musytaq, Qawanin al-Syari'ah Sayyid Dakhlan dan Ustman ibn Yahya, Syamsuri lil Faraidh, Bughyat al-Musytarsydin, al-Fiqh 'ala Madzahib al-'Arba'ah dan Mugni al-Muhtaj. (Ahmad Izzuddin, PROBLEMATIKA IMPLEMENTASI HUKUM ISLAM DI INDONESIA Studi Kasus Pernikahan Pujiono dan Lutfiana Ulfa, De Jure, Jurnal Syariah dan Hukum, Volume I Nomor 2 Agustus 2009, hlm. 3).
} 
Kompilasi Hukum Islam (KHI). ${ }^{70}$ Pembentukan KHI tidak hanya berkaitan dengan sumber hukum materiil, melainkan upaya untuk pembentukan hukum positif yang dapat diterapkan di Indonesia, dikarenakan munculnya perbedaan-perbedaan dalam menentukan penerapan hukum di Indonesia melalui lembaga Peradilan Agama. Perbedaan atau kesulitan-kesulitan tersebut muncul dari proses dan hasil ijtihad yang tidak dapat saling mengalahkan satu dengan lainnya. KHI muncul sebagai upaya untuk menghilangkan kesimpangsiuran dan penyeragaman sebagai pedoman fiqih Indonesia, terkait penyelesaian perkara-perkara masyarakat Muslim Indonesia di lembaga Peradilan Agama. ${ }^{71}$

KHI menjadi penting sebagai rujukan dan landasan putusan Peradilan Agama karena asas personalitas keislaman yang dianut oleh Peradilan Agama. Asas personalitas berkaitan dengan ketundukan terhadap kekuasaan Peradilan Agama, dikarenakan pengakuan terhadap diri seseorang yang mengaku dirinya sebagai pemeluk (agama)Islam. ${ }^{72}$

KHI merupakan suatu perwujudan hukum Islam yang khas Indonesia, pandangan ini dapat dilihat dari unsur-unsur sistem hukum nasional: ${ }^{73}$

1. Landasan ideal dan konstitusi KHI adalah Pancasila dan UndangUndang Dasar 1956. Ketentuan ini dimuat dalam konsideran Instruksi Presiden dan dalam Penjelasan Umum Kompilasi Hukum Islam yang disusun sebagai bagian dari sistem hukum nasional dan menjamin kelangsungan hidup beragama berdasarkan Ketuhanan Yang Maha Esa yang sekaligus merupakan perwujudan kesadaran masyarakat dan bangsa Indonesia.

2. KHI dilegalisasi oleh isntrumen hukum dalam bentuk Instruksi Presiden yang dilaksanakan oleh Keputusan Menteri Agama, dan merupakan bagian dari rangkaian peraturan perundang-undangan yang berlaku. Instruksi Presiden ini tidak mengurangi sifat legalitas dan otoritasnya, dikarenakan segala yang dirumuskan di dalamnya

\footnotetext{
${ }^{70}$ Kompilasi Hukum Islam (KHI) melalui Instruksi Presiden Nomor 1 Tahun 1991 (Abdul Gani Abdullah, Pengantar Kompilasi Hukum Islam dalam Tata Hukum Indonesia, Gema Insani Press, Jakarta, 1994, hlm. 62).

${ }^{71}$ Abdurrahman, Kompilasi Hukum Islam Di Indonesia, Akademika Pressindo, Jakarta, 1992, hlm. . 15-30.

72 Moh. Muhibbin, Abdul Wahid, Hukum Kewarisan Islam Sebagai Pembaharuan Hukum Positif di Indonesia, Sinar Grafika, Jakarta, 2009, hlm. 171.

73 Muchith A. Karim (editor), Pelaksanaan Hukum Waris di Kalangan Umat Islam Indonesia, Kementrian Agama Republik Indonesia, Badan Litbang dan Pustlitbang Kehidupan Keagamaan, Jakarta, 2010, hlm. 4-5.
} 
merupakan suatu kebutuhan akan ketertiban masyarakat Islam masa kini dan masa yang akan datang. Kandungan isi dari KHI disusun dan diupayakan berdasarkan keinginan dan kesadaran masyarakat yang membutuhkannya.

3. KHI dirumuskan dari tatanan hukum Islam yang bersumber dari alQuran dan Sunnah Nabi Muhammad saw yang bercorak keIndonesiaan.

Perkembangan hukum Islam memasuki akhir abad $20 \mathrm{M}$ mulai memasuki bidang ekonomi terutama bidang perbankan, dengan munculnya perbankan syariah. Undang-Undang Nomor 10 Tahun 1998 dan kebijakan hukum perbankan di Indonesia menganut sistem perbankan ganda (dual banking system). Kebijakan ini intinya memberikan kesempatan bagi bank-bank umum konvensional untuk memberikan layanan syariah melalui mekanisme islamic window dengan terlebih dahulu membentuk Unit Usaha Syariah (UUS). Akibatnya paska Undang-Undang ini muncul banyak bank konvensional yang ikut andil dalam memberikan layanan syariah kepada nasabahnya. ${ }^{74}$

Ketika hati dan pikiran telah sedemikian lama terkungkung oleh sistem ribawi, ide bank Islam yang dimunculkan oleh Majelis Ulama Indonesia seakanakan membuat umat Islam kesulitan mencari rujukan. UU Perbankan No. 7 tahun 1992 memberikan peluang berdirinya bank syariah. Sekarang, setelah bank syariah beroperasi tujuh tahun dan UU Perbankan No. 10 Tahun 1998 diterbitkan, beberapa bank akan mengubah sistem operasinya menjadi bank syariah, baik secara keseluruhan maupun hanya mendirikan cabang-cabang syariah. Sekali lagi umat Islam gamang mencari rujukan bagaimana mengkonversi bank-bank umum menjadi bank syariah. ${ }^{75}$

Kegamangan tersebut dapat diatasi dengan berbagai peraturan yang kemudian baik itu bersifat umum, teknis maupun aturan pelaksana dari perbankan syari'ah. Adapun aturan tersebut sampai akhir abad 20 adalah

1. Undang-Undang Nomor 7 tahun 1992 tentang Perbankan

\footnotetext{
${ }^{74}$ Abdul Ghofur Anshori, Sejarah Perkembangan Hukum Perbankan Syariah di Indonesia dan Implikasinya bagi Praktik Perbankan Nasional, La Riba Vol. II, No. 2, Desember 2008, hlm. 162. ${ }^{75}$ Santoso dan Suhadi, Periodisasi Perkembangan Hukum Perbankan Syariah Di Indonesia, Yudisia, Vol. 6, No. 1, Juni 2015, hlm. 129.
} 
2. Undang-Undang Nomor 10 tahun 1998 tentang Perubahan atas Undang-Undang Nomor 7 tahun 1992 tentang Perbankan

3. Undang-Undang Nomor 23 tahun 1999 tentang Bank Indonesia

4. Undang-Undang Nomor 7 tahun 1989 tentang Peradilan Agama:

\section{Penutup}

Hukum Islam merupakan padanan kata yang ditujukkan pada fiqih dalam tata hukum Indonesia. Hukum Islam berada di Indonesia bersamaan dengan masuknya Islam di Indonesia yaitu abad $7 \mathrm{M}$. Proses tumbuh dan berkembang hukum Islam belum mengalami institusional atau dilembagakan. Proses pelembagaan mulai terjadi pada era Kerajaan Islam, yang menempatkan pelembagaan yang berbeda-beda. Perbedaan itu muncul dipengaruhi oleh pemimpin atau raja penguasa kerajaan tersebut. Pada satu kerajaan raja dapat menjadi sekaligus qadhi, sebagaimana yang terjadi di Samudera Pasasi dengan rajanya Malikus Saleh. Keadaan ini berbeda dengan kerajaan Mataram Islam yang membedakan pembagian tugas. Raja memegang kekuasaan administrsi dan politik sedangkan ulama memegang peranan sebagai qadi.

Periode kolonial memiliki corak yang berbeda, pembagian tugas secara umum telah dilakukan, melaui penguatan formal terutama, terkait aturan hukum keluarga dan waris, melalui Compendium Freijer serta pengakuan peradilan agama yang dikenal pada zaman kolonial dengan priesterraad. Pengaturan secara legalitas formal secara khusus dipengaruhi oleh dua teori utama yaitu receptio in complexu yang dilekatkan pada Lodewijk Willem Christian van den Berg, teori lain yang mendominasi era kolonial Belanda di Indonesia adalah receptie. Teori receptie dicetuskan Christian Snouck Hurgronje, teori ini yang melatarbelakangi pencabutan kewenangan Pengadilan Agama memiliki kewenangan mandiri atau khusus dalam meyelesaikan permasalahan bagi umat Islam Indonesia.

Periode kemerekaan merupakan titik balik hukum Islam memiliki peran yang demikian luas sama halnya dengan era kerajaan Islam, setidaknya itu merupakan pandangan yang diharapkan. Pengharapan ini mula menunjukkan ketidakpastian, keadaan ini muncul sebagai konsekuensi kompromi yang 
dilakukan oleh kelompok Islam dan Kelompok Kebangsaan. Peristiwa yang mengantarkan hukum Islam berada pada sisi legalitas formal yang memiliki kedudukan dengan era kolonial mulai mengalami perubahan. Perubahan ini ditunjukkan dengan munculnya berbagai peraturan yang memberikan keleluasaan bagi umat Islam untuk mengamalkan ajaran Islam yang dipekuat melalui legalitas formal.

Adapun legalitas formal yang memberikan pengaruh terhadap pengamalan kehidupan beragama umat Islam Indonesia dengan dukungan legalitas formal aturan hukum adalah sebagai berikut:

1. Undang-Undang No. 1 Tahun 1974 Tentang Perkawinan,

2. Undang-Undang Nomor 7 tahun 1992 tentang Perbankan,

3. Undang-Undang Nomor 10 tahun 1998 tentang Perubahan atas UndangUndang Nomor 7 tahun 1992 tentang Perbankan

4. Undang-Undang, Nomor 23 tahun 1999 tentang Bank

5. Indonesia, Undang-Undang Nomor 7 tahun 1989 tentang Peradilan Agama,

6. Instruksi Presiden Nomor 1 Tahun 1981 Tentang Kompilasi Hukum Islam.

\section{Daftar Pustaka}

Buku:

A. Mukti Ali, Alam Pikiran Islam Modern Di Indonesia dan Modern Islamic Thaought In Indonesia, Jajasan Nida, Jogjakarta, 1969.

A. Qadri Azizy, Eklektisisme Hukum Nasional, Gama Media, Yogyakarta, 2002.

A. Wasit Aulawi, Sejarah Perkembangan Hukum Islam, dalam Dimensi Hukum Islam Dalam Sistem Hukum Nasional, Gema Insani Press, Bandung, 1996.

Abdul Gani Abdullah, Pengantar Kompilasi Hukum Islam dalam Tata Hukum Indonesia, Gema Insani Press, Jakarta, 1994

Ajid Tohir, Studi Kawasan Dunia Islam Perspektif Etno-Linguistik dan Geo-Politik, Rajawali Press, Jakarta, 2011.

Ali Yafie, Menggagas Fiqh Sosial, Mizan, Bandung, 1994.

Amien Husein Nasution, Hukum Kewarisan (Suatu Analisis Komparatif Pemikiran

Mujtahid dan Kompilasi Hukum Islam), Rajawali Pers, Jakarta, 2012.

Amak F.Z., Proses Undang-undang Perkawinan, Al-Ma'arif, Bandung, 1976. 
Anwar Harjono, Hukum Kewarisan Bilateral Menurut al-Quran (Komentar Singkat Atas Teori Prof, Hazairi), dalam Pembaharuan Hukum Islam di Indonesia, Yayasan Penerbit Universitas Indonesia, Jakarta, 1976.

Bismar Siregar, Prof. Mr. Dr. Hazairin Seorang Mujahidin Penegak Hukum Berdasar Ke -Tuhanan Yang Maha Esa, dalamPEmbaharuan Hukum Islam di Indonesia, Yayasan Penerbit Universitas Indonesia, Jakarta, 1976.

Cik Hasan Bisri (ed), Logos Wacana Ilmu, Jakarta, 1999.

Daniel S. Lev, Islamic Courts in Indonesia (A Study in the Political Bases of Legal Institutions), University of California Press, Los Angeles, 1972.

Hamka, Sejarah Umat Islam IV, Bulan Bintang, Jakarta, 1976.

Ismail Suny, Kedudukan Hukum Islam dalam Sistem Ketatanegaraan Indonesia, dalam Hukum Islam di Indonesia Perkembangan dan Pembentukannya, Rosdakarya, Bandung, 1991.

H.M. Rosjidi, Snouck Hurgronje Seorang Pelopor dalam Mempelajari Islam, dalam A. Adaby Darban, Snouck Hurgronje dan Islam di Indonesia, Yogyakarta.

Ismuha, Islam Dan Masyarakat Aceh dalam Agama dan Perubahan Sosial, Rajawali, 1983.

Juhaya S. Praja, Hukum Islam di Indonesia Perkembangan dan Pembentukannya, Rosdakarya, Bandung, 1991.

K.H.O. Gadjahnata, Sri-Edi Swasono, Masuk dan berkembangnya Islam di Sumatera Selatan, UI-Press, Jakarta, 1986.

M. Idris Ramulyo, Asas-Asas Hukum Islam (Sejarah Timbul dan Berkembangnya Kedudukan Hukum Islam dalam Sistem Hukum di Indonesia), Sinar Grafika, Jakarta, 1997.

Moh. Idris Ramulto, Asas-Asas Hukum Islam (Sejarah Timbul dan Berkembangnya Kedududukan Hukum Islam dalam Sistem Hukum Indonesia), Sinar Grafika, Jakarta, 1995.

Muhammad Daud Ali, Hukum Islam, Rajawali Pers, Jakarta, 1998.

Munawir Sjadzali, Islam Dan Tata Negara (ajaran, sejarah dan pemikiran), UIPress, Jakarta, 1990.

Sahal Mahfudz, Nuansa Fikih Sosial, LKiS, Yogyakarat, 1994.

Saidus Syahar, Asas-Asas Hukum Islam, Alumni, Bandung, 1974.

Sajuti Thalib, Receptio In Complexu, Theorie Receptie Dan Receptio A Contrario, dalam Pembaharuan Hukum Islam di Indonesia, Yayasan Penerbit Universitas Indonesia, Jakarta, 1976.

Soediman Kartohadiprodjo, Beberapa Pemikiran Sekitar Pancasila, Alumni, Bandung, 1980.

T. M. Hasbi ash-Shiddieqy, Fiqhul Mawaris (Hukum-Hukum Warisan Dalam Syariat Islam, Bulan Bintang, Jakarta, 1973.

Taufik Abdullah (ed), Agama Dan Perubahan Sosial, Rajawali Pers, Jakarta, 1983.

Thomas F. O’Dea, Sosiologi Agama (terj. Yasogama), Rajawali Pers, Jakarta, 1992.

Zaini Ahmad Noeh, Abdul Basit Adnan, Sejarah Singkat Pengadilan Agama Islam di Indonesia, Bina Ilmu, Surabaya, 1983. 
Jurnal:

A. Kardiyat Wiharyanto, Pergantian Kekuasaan Di Indonesia Tahun 1800, SPPS Vol. 21, No. 1, April 2007.

Abd. Ghofur, Tela'ah Kritis Masuk dan Berkembangnya Islam di Nusantara, Jurnal Ushuluddin Vol. XVII No. 2, Juli 2011.

Abdul Halim, Membangun Teori Politik Hukum Islam Di Indonesia, Jurnal Ahkam, Vol. XIII, No. 2, Juli 2013.

Ahmad Izzuddin, PROBLEMATIKA IMPLEMENTASI HUKUM ISLAM DI INDONESIA Studi Kasus Pernikahan Pujiono dan Lutfiana Ulfa, De Jure, Jurnal Syariah dan Hukum, Volume I Nomor 2 Agustus 2009.

Alma'arif, Islam Nusantara: Studi Epistemologis Dan Kritis, ANALISIS: Jurnal Studi Keislaman, Volume 15, Nomor 2, Desember 2015..

Chamim Tohari, Fiqh Keindonesiaan: Transformasi Hukum Islam Dalam Sistem Tata Hukum Di Indonesia, ANALISIS: Jurnal Studi Keislaman, Volume 15, Nomor 2, Desember 2015.

EMK. Alidar, Hukum Islam Di Indonesia Pada Masa Orde Baru (1966-1997), Legitimasi, Vol.1 No. 2, Januari-Juni 2012

Effendi, Politik Kolonial Belanda Terhadap Islam Di Indonesia Dalam Perspektif Sejarah (Studi Pemikiran Snouck Hurgronye), Jurnal TAPIs Vol.8 No.1 Januari-Juni 2012,

Feirul Maliq Intajalle, et all, Islamic Inheritance Law Among Muslim Minority Countries in Southeast Asia, Middle-East Journal of Scientific Research 12 (1), (2012).

Kees De Jong, Dari Perpisahan Kolonial Ke Perjuangan Nasional Bersama Sejarah Singkat Hubungan Islam-Kristen Di Indonesia ( $\pm 1520-1949)$, Gema Teologi Vol. 36, No. 2, Oktober 2012.

Khabibi Muhammad Luthfi, Islam Nusantara: Relasi Islam dan Budaya Lokal, Shahih Vol. 1, Nomor 1, Januari-Juni 2016

Khoiruddin Buzama, Pemberlakuan Teori-Teori Hukum Islam Di Indonesia, AL'ADALAH Vol. X, No. 4 Juli 2012.

MB Hooker, Introduction: Islamic Law in South-east Asia, Asian Law Journal Vol 4, 2002.

M. Dahlan M., Dinamika Perkembangan Islam Di Asia Tenggara Perspektif Histori, Jurnal Adabiyah Vol. XIII nomor 1/2013.

M. Shohibul Imam, Hukum Islam Dalam Pergumulan Politik Hukum Nasional Era Reformasi, Al-Tahrir, Vol. 13, No. 2 November 2013.

M. Yakub, Perkembangan Islam Indonesia, Kalam: Jurnal Studi Agama dan Pemikiran Islam, Volume 7, Nomor 1, Juni 2013.

Mahsun, Genesis Pemikiran Hukum Islam Nusantara (Studi Pengaruh Islam Pertama Terhadap Perkembangan Pemikiran Dan Politik Hukum Islam Nusantara Klasik). al-Mabsut Vol. 9, No. 12015.

Maimunah, Sistem Pendidikan Surau : Karakteristik, Isi Dan Literatur Keagamaan, TA'DIB, Vol. XVII, No. 02, Edisi Desember 2012.

Mark E. Cammack and R. Michael Feener, The Islamic Legal System In Indonesia, Pacific Rim Law \& Policy Journal Vol. 21 No. 1, January 2012. 
Moh. Muhibbin, Abdul Wahid, Hukum Kewarisan Islam Sebagai Pembaharuan Hukum Positif di Indonesia, Sinar Grafika, Jakarta, 2009.

Muchith A. Karim (editor), Pelaksanaan Hukum Waris di Kalangan Umat Islam Indonesia, Kementrian Agama Republik Indonesia, Badan Litbang dan Pustlitbang Kehidupan Keagamaan, Jakarta, 2010.

Muhammad Syarif, Teori-Teori Masuknya Islam ke Wilayah Timur Indonesia, Jurnal Fakultas Ilmu Budaya Universitas Indonesia, 2014.

Murdan, Pluralisme Hukum (Adat Dan Islam) Di Indonesia, Mahkamah, Vol. 1, No. 1, Juni 2016.

Muslim, Perkembangan Studi Hukum Islam Di Indonesia, al-'Adalah Vol. XI, No. 1 Januari 2013.

Rahimin Affandi Abd Rahim, Paizah Hj Ismail, Mohd Kamil Abd Majid, Nor Hayati Md. Dahlal, Batu Bersurat Terengganu: Satu Tafsiran Terhadap Pelaksanaan Syariah Islam, Jurnal Fiqh, No. 7 (2010).

Saifullah SA, Umat Islam Di Filipina Selatan Sejarah, Perjuangan Dan Rekonsiliasi, ISLAMICA, Vol. 3, No. 1, September 2008

Sirajuddin M, Wacana Penerapan Hukum Islam dalam Tinjauan Politik Hukum Nasional, Sosio-Religia, Vol. 8, No. 3, Mei 2009.

Sirojul Munir, Pengaruh Hukum Islam Terhadap Politik Hukum Indonesia, Jurnal Istinbath Vol. 13, No.2, Desember 2014.

Suriana, Dimensi Historis Pendidikan Islam (Masa Pertumbuhan, Perkembangan, Kejayaan, Dan Kemunduran), Jurnal Pionir, Volume 1, Nomor 1, JuliDesember 2013.

Sirojul Munir, Pengaruh Hukum Islam Terhadap Politik Hukum Indonesia, Vol. 13, No.2, Desember 2014.

\section{Seminar:}

Aden Rosadi, Legislasi Dan Politik Hukum Islam Di Indonesia, Seminar Nasional Tentang Legislasi dan Politik Hukum di Indonesia, STAIN Jurai Siwo Metro, 31 Mei 2016.

Syed Hamid bin Syed Jaafar Albar, The Role of Islamic Civilisation in Strengthening the Foreign Relations between Countries of ASEAN, Proceedings ASEAN Community Conference 2015, Published by nstitute of Islam Hadhari Universiti Kebangsaan Malaysia together with Faculty of Human Ecology Universiti Putra Malaysia Selangor.

Zainal Arifin Hoesein, Pembentukan Hukum Dalam Perspektif Pembaruan, Volume 1 Nomor 3, Desember 2012

\section{Peraturan Perundang-Undangan:}

Undang-Undang Nomor 7 Tahun 1989 Tentang Peardilan Agama

Instruksi Presiden Nomor 1 Tahun 1991Tentang Kompilasi Hukum Islam

Surat Edaran Biro Peradilan Agama tanggal 18 Februari 1958 Nomor B/I/735

Tentang Peraturan pelaksana PP No. 45 Tahun 1957 tentang Pembentukkan Peradilan Agama di luar Jawa dan Madura. 